Juria

\title{
Bibliografie zum Richterrecht - Update 54
}

Das Update der Bibliografie enthält seit der Ausgabe 2006/4 von «Justice - Justiz - Giustizia» jeweils die neu veröffentlichten Monographien und Aufsätze im Themenbereich der Richterzeitung. Ab Ausgabe 2021/3 erfolgt die Aufbereitung in Zusammenarbeit mit dem Schweizerischen Institut für Judikative SIfJ; erfasst werden zusätzlich ca. 150 internationale Zeitschriften und die Kataloge von rund 25 internationalen Bibliotheken. Eine Gesamtübersicht der Bibliografie finden Sie auf: https://sifj.ch/dokumentation/bibliography/

Beitragsart: Literature

Zitiervorschlag: Juria, Bibliografie zum Richterrecht - Update 54, in: «Justice - Justiz - Giustizia» $2021 / 3$ 
Ainsley Caitlin, Carrubba Cliff, Vanberg Georg, The Future Matters; Journal of Law and Courts; Vol. 9 Issue 1, pp. 1-25, 2021

Anleu Sharyn L. Roach, Judging and emotion: a socio-legal analysis; London; Routledge, 2021

Anzinger Heribert M., 10 Jahre Modria: KMS und Online- Mediation auf dem Weg zur Digitalisierung der Justiz -Teil 2; Zeitschrift für Konfliktmanagement ZKM; März 21

Anzinger Heribert M., 10 Jahre Modria: KMS und Online- Mediation auf dem Weg zur Digitalisierung der Justiz - Teil 1; Zeitschrift für Konfliktmanagement; Vol. 24 Issue 2, pp. 53-57, 2021

Appleby Gabrielle, The judge, the judiciary, and the court: individual, collegial and institutional judicial dynamics in Australia; Cambridge, Cambridge University Press, 2021

Arajärvi Noora, The Core Requirements of the International Rule of Law in the Practice of States; Hague Journal on the Rule of Law; Vol. 13 Issue 1, pp. 173-193, 2021

Arzoz Xabier, The Constitutional Court of Spain; Zeitschrift für öffentliches Recht; Vol. 76 Issue 2, pp. 413, 2021

Bachmann Simon, The impact of third-party funding on security for costs requests in international arbitration proceedings in Switzerland: why and how third-party fundings should be considered under the swiss lex arbitri; Bulletin ASA; 2020/842

Bagashka Tanya, Tiede Lydia Brashear, The Influence of Procurator Generals in Constitutional Review; Journal of Law and Courts; Vol. 9 Issue 1, pp. 189-214, 2021

Bandes Susan A., Feeling and thinking like a lawyer: cognition, emotion and the practice and progress of law; Fordham Law Review; Vol. 89

Barnes Victoria, Whewell Emily, Judicial Biography in the British Empire; Indiana Journal of Global Legal Studies; Vol. 28 Issue 1, pp. 1, 2021

Barsotti Vittoria, Dialogues on Italian constitutional justice: a comparative perspective; Abingdon, Oxon; Routledge, 2021

Baude William, Precedent and Discretion; The Supreme Court Review; Vol. 2019, pp. 313-334, 2020

Baudenbacher Carl, Judicial Independence - Memoirs of a European Judge; Cham; Springer Nature Switzerland AG, 2019

Birkenkötter Hannah, Hat der Begriff der Rechtsstaatlichkeit ein emanzipatorisches Potenzial?; Kritische Justiz; Vol. 54 Issue 2, pp. 172-181, 2021

Bohnet François, Professions d'avocat-e, de notaire et de juge; Basel; Helbing Lichtenhahn, 2021

Bonica Adam, The judicial tug of war: how lawyers, politicians, and ideological incentives shape the American judiciary; Cambridge; Cambridge University Press, 2021

Breyer Stephen G., A Justice and a Friend; Columbia Law Review; Vol. 121:5 
Bricker Benjamin, Consensus Decision Making: A Comparative Analysis of Judging and Judicial Deliberations; Justice System Journal; Vol. 42 Issue 1, pp. 25-49, 2021

Broberg Morten P., Preliminary references to the European Court of Justice - 2. ed.; Oxford [u.a.]; Oxford Univ. Press, 2014

Büeler Jasmin, E-justice in der Strafjustiz zwischen Effizienz und Legitimation; Smart criminal justice; der Einsatz von Algorithmen in der Polizeiarbeit und Strafrechtspfleg; Seiten 59-79; 2021

Bühler René, Cudré-Mauroux Philippe, Gilliéron Philippe, Jendly Manon, Lassègue Jean, Manzoni Patrik, Fink Daniel, Arnold Jörg, Strafjustiz zwischen künstlicher Intelligenz und prädiktiven Algorithmen: La justice pénale entre intelligence artificielle et algorithmes prédictifs; Basel; Helbing \& Lichtenhahn, 2021

Bussjäger Peter, The Influence of the Austrian Constitutional Court on the Constitutional Court of the Principality of Liechtenstein; Zeitschrift für öffentliches Recht; Vol. 76 Issue 2, pp. 439, 2021

Canihac Hugo, Is Constitutional Pluralism (Il)liberal? On the Political Theory of European Legal Integration in Times of Crisis; German Law Journal; Volume 22, Issue 4, pp. 491-505, June 2021

Capps Patrick, Olsen Henrik Palmer, Explaining power and authority in international courts; Leiden Journal of International Law; Vol. 34 Issue 3, pp. 533-546, 2021

Carnwath Robert, Where Next for Judicial Review? Some Lessons from Eight Years in the Supreme Court; Judicial Review; Vol. 25 Issue 4, pp. 321-335, 2020

Castelliano Caio, Grajzl Peter, Alves Andre, Watanabe Eduardo, Adjudication Forums, Specialization, and Case Duration: Evidence from Brazilian Federal Courts; Justice System Journal; Vol. 42 Issue 1, pp. 50-77, 2021

Chauhan Abe, Towards the Systemic Review of Automated Decision-Making Systems; Judicial Review; Vol. 25 Issue 4, pp. 285-295, 2020

Darák Péter, Rechtswege - Urteilswirkungen; Heidelberg; Universitätsverlag Winter GmbH, 2020

de Castelnau Régis, Une justice politique: des années Chirac au système Macron, histoire d'un dévoiement; Paris; l'Artilleur, 2020

Deb Sibnath, Subhalakshmi G., Delivering justice: issues and concerns; Abingdon, Oxon; Routledge, Taylor \& Francis Group, 2021

Delledonne Giacomo, Imitation, Adaptation, and Further Development: The German Federal Constitutional Court and the Austrian Model; Zeitschrift für öffentliches Recht; Vol. 76 Issue 2, pp. 451,2021

Deutscher Richterbund, Handbuch der Justiz 2020/2021; C.F. Müller Verlag, 2020

Dias João Paulo, Casaleiro Paula, Lima Teresa Maneca, Gomes Conceição, Judicial Responses to COVID-19 Attack: Impacts on the Working Conditions of Portuguese Courts; International Journal for Court Administration; Vol. 12 Issue 2, 2021 
Diener Maren, Neonazis im Referendariat? Konsequenzen aus der Entscheidung des OLG Dresden zum Fall Brian E.; Kritische Justiz; Vol. 54 Issue 2, pp. 214-217, 2021

Downs Donald Alexander, Supreme Court Nominations at the Bar of Political Conflict: The Strange and Uncertain Career of the Liberal Consensus in Law; Law \& Social Inquiry; Vol. 46 Issue 2, pp. 540-571, 2021

Dryzek John S., Democratizing global justice: deliberating global goals; Cambridge; Cambridge University Press, 2021

Drzalic Jana Johanna, Gutachten und Richter im Strafprozess; Zürich/Basel/Genf; Schulthess, 2021; Dissertation, Universität Zürich, 2020

Drzalic Jana Johanna, Gutachten und Richter im Strafprozess; Zürich/Basel/Genf; Schulthess, 2021

Duarte d'Almeida Luís, What Is It to Apply the Law?; Law and Philosophy; Vol. 40 Issue 4, pp. 361-386, 2021

Dürst Jennifer, «Gerüchteküche» um die Mediation; Anwaltsrevue; 2020/454

Eberhard Harald, The Austrian Constitutional Court after 100 Years: Remodelling the Model?; Zeitschrift für öffentliches Recht; Vol. 76 Issue 2, pp. 395, 2021

Effer-Uhe Daniel, Mohnert Alica, Psychologie für Juristen; Baden-Baden; Nomos, 2019

Enescu Raluca, Penal Orders and the Role of Prosecutors in Switzerland; Journal of Legal Studies; Vol. 26 Issue 40, pp. 125-141, 2020

Ernst Silvia, Transparenz in der Judikative; Baden-Baden; Nomos; 2021

Ervo Laura, Letto-Vanamo Pia, Nylund Anna, Rethinking Nordic Courts; Cham; Springer, 2021

Essodjilobouwè Peketi, L'homologation judiciaire des actes juridiques: l'impossible théorie générale; Mare \& Martin, 2020

Fabra-Zamora Jorge Luis, The theoretical puzzles of non-state legal phenomena; Transnational Legal Theory; Vol. 12 Issue 1, pp. 110-143, 2021

Fabri Marco, Will COVID-19 Accelerate Implementation of ICT in Courts?; International Journal for Court Administration; Vol. 12 Issue 2, 2021

Fasel Urs, Eugen Huber als Richter 1881-1882; Bern; Stämpfli Verlag, 2021

Fellmann Jeremias, Die bundesgerichtliche Rechtsprechung zu Art. 30 Abs. 1 BV; «Justice - Justiz - Giustizia» 2021/2

Feteris Maarten, Roadmap on Comparative Law in the Case-Law and Practice of the Supreme Courts of the EU; Utrecht Law Review; Vol. 17 Issue 1, pp. 6, 2021

Fischer Jonas, ADR Alternative Dispute Resolution: Verhandlung, Mediation, Schlichtung, Schiedsgerichtsbarkeit, Schiedsgutachten, Hybride ADR-Verfahren; Zürich/St. Gallen; Dike, 2021 
Forrest Katherine B., When machines can be judge, jury, and executioner: justice in the age of artificial intelligence; Hackensack, New Jersey; World Scientific, 2021

Franck Fleerackers, La peau du juge; Bruxelles; Larcier, 2021

Fusco Elisa, Laurenzi Martina, Maggi Bernardo, Length of Trials in the Italian Judicial System: An Efficiency Analysis by Macro-Area; Justice System Journal; Vol. 42 Issue 1, pp. 78-105, 2021

Gamper Anna, Dangerous or Endangered Constitutional Courts? A View from among and within the Branches of Power; Zeitschrift für öffentliches Recht; Vol. 76 Issue 2, pp. 331, 2021

Gerland Heinrich Balthasar, Die englische Gerichtsverfassung: eine systematische Darstellung; Leipzig; Göschen, 2021

Gill Nick, Allsopp Jennifer, Burridge Andrew, The tribunal atmosphere: On qualitative barriers to access to justice; Elsevier, 2021

Girsberger Daniel, International arbitration: comparative and Swiss perspectives; 4. Aufl.; Zurich/Basel/Genf/Baden-Baden; Schulthess \& Nomos, 2021

Girsberger Daniel, Selected papers on international arbitration; Bern; Stämpfli, 2021

Groupe de travail de la Cour de cassation, Quelle indépendance financière pour l'autorité judiciaire?; 2021

Guarnieri Carlo, Pederzoli Patrizia, The judicial system: the administration and politics of justice; Cheltenham, UK/Northampton, USA; Edward Elgar Publishing Limited, 2020

Habermann Julia, Singelnstein Tobias, Sanktionierungsvorstellungen und Einstellungen des deutschen Justizpersonals im Strafrecht; Zeitschrift für Rechtssoziologie - The German Journal of Law and Society; Vol. 40 Issue 1-2, pp. 52-89, 2021

Harnack Klaus, Wesenszüge des digitalen Streits - Online Verhandeln, Schlichten und Richten; Zeitschrift für Konfliktmanagement ZKM; März 2021

Hazelton Morgan L. W., Judicial Impact and Factual Allegations; Journal of Law and Courts; Vol. 9 Issue 1, pp. 159-188, 2021

Helmersen Sondre Torp, The EFTA Court and International Law; Oslo Law Review; Vol. 8 Issue 01, pp. 30-46, 2021

Hoefer Bernd, Ingwersen-Stück Hege, Sönke Gerhold, Formulare für Referendare; BadenBaden; Nomos, 2021

Hoxhaj Andi, The EU Rule of Law Initiative Towards the Western Balkans; Hague Journal on the Rule of Law; Vol. 13 Issue 1, pp. 143-172, 2021

Hutchinson Terry, Court appearances via video link for young people in detention in Queensland; Australian Institute of Criminology, 2021

Hwang Shu-Perng, Ist die Grundnorm demokratisch?; Zeitschrift für öffentliches Recht; Vol. 76 Issue 2, pp. 501, 2021

Igreja Matos José, Ein Stück Hoffnung geben; «Justice - Justiz - Giustizia» 2021/2 
Jeli Ivana, Kapetanakis Dimitrios, European Judicial Supervision of the Rule of Law: The Protection of the Independence of National Judges by the CJEU and the ECtHR; Hague Journal on the Rule of Law; Vol. 13 Issue 1, pp. 45-77, 2021

Jestaedt Matthias, Grundrechtsentfaltung im Gesetz - Studien zur Interdependenz von Grundrechtsdogmatik und Rechtsgewinnungstheorie; Tübingen; Mohr Siebeck, Jus Publicum 50, 1999

Jutzi Marc, Der Steuerrichter im Internet -- Zulässigkeit und Validität von Internetrecherchen bei der Sachverhaltsermittlung; «Justice - Justiz - Giustizia» 2021/2

Kaczmarczyk, Michal, The differentiation of international arbitration and the claim for democracy; Transnational Legal Theory; Vol. 12 Issue 1, pp. 78-109, 2021

Kettiger Daniel, Anonymisierung von Urteilen; Basel; Helbing Lichtenhahn Verlag, 2021

Kettiger Daniel, Lienhard Andreas, Swiss Courts Facing the Challenges of COVID-19; International Journal for Court Administration; Vol. 12 Issue 2, 2021

Kidd Taylor, Implicit and Explicit Attitudes Toward Prosecutors and Defense Attorneys; Justice System Journal; Vol. 42 Issue 1, pp. 3-24, 2021

Kleinberg Jon, Lakkaraju Himabindu, Leskovec Jure, Ludwig Jens, Mullainathan Sendhil, Human Decisions and Machine Prediction; The Quarterly Journal of Economics; Volume 133, Issue 1, Pages 237-293, February 2018

Kosař David, Spáč Samuel, Post-communist Chief Justices in Slovakia: From Transmission Belts to Semi-autonomous Actors?; Hague Journal on the Rule of Law; Vol. 13 Issue 1, pp. 107-142, 2021

Krewson Christopher N., Owens Ryan J., Public Support for Judicial Philosophies; Journal of Law and Courts; Vol. 9 Issue 1, pp. 89-110, 2021

Kritz Neil J., Transitional justice: how emerging democracies reckon with former regimes; Washington; United States Institute of Peace Press, 2021

Kyle Brett J., Military courts, civil-military relations, and the legal battle for democracy: the politics of military justice; Abingdon, Oxon; Routledge, 2021

Lacny Justyna, The Rule of Law Conditionality Under Regulation No 2092/2020-Is it all About the Money?; Hague Journal on the Rule of Law; Vol. 13 Issue 1, pp. 79-105, 2021

Leuzinger Susanne, Die Internationale Juristenkommission und ihr Einsatz für die richterliche Unabhängigkeit; «Justice - Justiz - Giustizia» 2021/2

Levy Cinthia, Médiation judiciaire: volontaire ou obligatoire? : les articles 213, 214 et 297 al. 2 CPC, 307 et 314 CC, 8 al. 1 LF-EEA; Anwaltsrevue; 2020/446

Lurie Guy, Ministerial Emergency Powers Over Court Administration in the Israeli Judiciary; International Journal for Court Administration; Vol. 12 Issue 2, 2021

Mack Kathy, Roach Anleu Sharyn, Entering the Australian Judiciary: Gender and Court Hierarchy; Law \& Policy; Vol. 34 Issue 3, pp. 313-347, 2012 
Magunna P., Der aufsichtführende Richter bei den Preussischen Amtsgerichten, seine Rechte und seine Pflichten; 3. Auflage; Oldenburg; DeGruyter, 2020

Mak Elaine, Travelling with Judges: Brief Reflections on the Roadmap on Comparative Law Developed by the Network of Presidents of the Supreme Judicial Courts of the European Union; Utrecht Law Review; Vol. 17 Issue 1, pp. 1-5, 2021

Marina Bletsas, Viele Stimmen - ein Urteil: zur polyphonen Argumentation von Rechtsprechung: ein theoretisch-methodologischer Vorschlag am Beispiel des italienischen Verfassungsgerichtsurteils; Frankfurt am Main; Vittorio Klostermann, 2021

Martenczuk Bernd, Rechtsbindung und Rechtskontrolle des Weltsicherheitsrats; Berlin; Duncker \& Humblot, 2021

Masood Ahmed, Alternative Dispute Resolution During the Covid-19 Crisis and Beyond; King's Law Journal; Volume 32, 2021 - Issue 1: Covid-19: Political Responses and Legal Consequences

Materna Markus, Richter der eigenen Sache: die «Selbstexkulpation» der Justiz nach 1945, dargestellt am Beispiel der Todesurteile bayerischer Sondergerichte; Baden-Baden; Nomos, 2021

McAlister Merritt, Missing Decisions (July 15, 2020); 169 University of Pennsylvania Law Review 1101,2021

Meurant Cédric, Le rôle du service juridique du Conseil constitutionnel; Equipe de droit public de Lyon; Université Jean Moulin - Lyon 3 (UJML); Uni... - HAL CCSDInstitut Francophone pour la Justice et la Démocratie, 2021

Meurant Cédric, Les collèges de déontologie des juridictions françaises; Equipe de droit public de Lyon; Université Jean Moulin - Lyon 3 (UJML); Uni... - HAL CCSDInstitut Francophone pour la Justice et la Démocratie, 2021

Meyer Ulrich, Probleme und Änderungsbedarf aus Sicht der Schweizer Judikative; «Justice - Justiz - Giustizia» 2021/2

Mize Selene E., Disciplining legal practitioners in New Zealand; International Journal of the Legal Profession; Vol. 28 Issue 2, pp. 159-180, 2021

Moreau Pierre, Lenaerts Jean-Sébastien, Biemar Bénédicte, Chantry Valérie, Fry Ariane et al., Principes généraux: l’organisation judiciaire; Bruxelles; La Charte, 2021

Moyer Laura P., The Role of Case Complexity in Judicial Decision Making; Law \& Policy; Vol. 34 Issue 3, pp. 291-312, 2012

Muschietti Giuseppe, Cronaca di un dialogo a distanza; «Justice - Justiz - Giustizia» 2021/2

N.N., Appointment of Arbitrators in the Changing ISDS Landscape; 2021; Swiss Review of International and European Law; vol. 31, no. 2, p. 231-240, 2021

N.N., Le cours de la justice et la liberté de l'information: le droit à l'information sur la justice: open data, droit d'acces aux décisions de justice et à l'information judiciaire; Paris; Editions Dalloz, 2021 
N.N., Relinquishment of jurisdiction contra legem: The European Court of Human Rights' decision in Grzda v. Poland; 2021

Naomi Creutzfeldt, Alternative Streitbeilegung und vulnerable Gruppen; Zeitschrift für Konfliktmanagement; Vol. 24 Issue 3, pp. 118-120, 2021

Nolan James L., Reinventing Justice: The American Drug Court Movement; Princeton, NJ; Princeton University Press, 2021

Oesch Matthias, Switzerland-EU Bilateral Agreements, the Incorporation of EU Law and the Continuous Erosion of Democratic Rights; Yearbook of European Law; Vol. 39, pp. 602-639, 2021

Oliveira Leonardo V. P. de, Access to justice in arbitration: concept, context and practice; Alphen aan den Rijn; Wolters Kluwer, 2021

Ollivier Nicholas, Banking and finance disputes: to arbitrate or not to arbitrate, that is the question; Schweizerische Zeitschrift für Wirtschafts- und Finanzmarktrecht: SZW; 2020/449

Palermo Giulio, Leveraging the standard of «ex aequo et bono» to increase diversity, flexibility and efficiency: insights from the basketball arbitral tribunal; Bulletin ASA; 2020/868

Pantazi Myrto, Klein Olivier, Kissine Mikhail, Is justice blind or myopic? An examination of the effects ofmeta-cognitive myopia and truth bias on mock jurors and judges; Judgment and Decision Making; Vol. 15, No. 2, pp. 214-229, March 2020

Paris Marion, Arbitrage contemporain à Art Basel ?; Bulletin ASA; 2020/619

Payandeh Mehrdad, Judikative Rechtserzeugung - Theorie, Dogmatik und Methodik der Wirkungen von Präjudizien; Tübingen; Mohr Siebeck, JusPubl 265, 2017

Pech Laurent, Wachowiec Patryk, Mazur Dariusz, Poland's Rule of Law Breakdown: A Five-Year Assessment of EU's (In)Action; Hague Journal on the Rule of Law; Vol. 13 Issue 1, pp. 1-43, 2021

Phelan William, Great judgments of the European Court of Justice: rethinking the landmark decisions of the foundational period; Cambridge; Cambridge University Press, 2021

Popotas Costas, COVID-19 and the Courts. The Case of the Court of Justice of the European Union (CJEU); International Journal for Court Administration; Vol. 12 Issue 2, 2021

Proelss Alexander, Bundesverfassungsgericht und überstaatliche Gerichtsbarkeit - Prozedurale und prozessuale Mechanismen zur Vermeidung und Lösung von Jurisdiktionskonflikten; Tübingen; Mohr Siebeck, JusPubl 235, 2014

Provost René, Rebel courts: The administration of justice by armed insurgents; New York, NY; Oxford University Press, 2021

Rattan, Jyoti, Rattan, Vijay, "The COVID-19 Crisis - the New Challenges Before the Indian Justice and Court Administration System»; International Journal for Court Administration; Vol. 12 Issue 2, 2021

Reiter Catherine, Mosimann Hans-Jakob, Der Belastungsausgleich zwischen Richterinnen und Richtern; «Justice - Justiz - Giustizia» 2021/2 
Riegger Stephan, Die zeitliche Wirkung von Urteilen des EuGH: Massgaben des Unionsrechts und Reaktionsmöglichkeiten mitgliedstaatlicher Gerichte; Baden Baden; Nomos, 2021

Rogol Natalie C., Montgomery Matthew D., Seeking Information; Journal of Law and Courts; Vol. 9 Issue 1, pp. 49-68, 2021

ROLAND Rechtsreport 2021, Schlechte Noten für die Justiz; Zeitschrift für Konfliktmanagement; Vol. 24 Issue 2, pp. 76-77, 2021

Rosenthal Maoz, Barzilai Gad, Meydani Assaf, Judicial Review in a Defective Democracy; Journal of Law and Courts; Vol. 9 Issue 1, pp. 137-157, 2021

Rossner Meredith, Remote rituals in virtual courts; Journal of Law and Society; Vol. 48 Issue 3, pp. 334-361, 2021

Röthemeyer Peter, Wie bekannt ist Mediation wirklich?; Zeitschrift für Konfliktmanagement; Vol. 24 Issue 3, pp. 94-96, 2021

Russo Alfio, Les modes de désignation des juges : étude de droit constitutionnel suisse et comparé; Basel; Helbing Lichtenhahn, 2021

Saitto Francesco, The Camel's Dilemma. Critical Reflections on the Political Nature of Constitutional Courts; Zeitschrift für öffentliches Recht; Vol. 76 Issue 2, pp. 353, 2021

Sanders Anne, Fragen zur richterlichen Unabhängigkeit in der Schweiz aus Europäischer Sicht; «Justice - Justiz - Giustizia» 2021/2

Sanders Anne, Video-Hearings in Europe Before, During and After the COVID-19 Pandemic; International Journal for Court Administration; Vol. 12 Issue 2, 2021

Sátiro Renato Máximo, Martins Jessica Vitorino, De Moraes Sousa Marcos, The Courts in the Face of the COVID-19 Crisis: An Analysis of the Measures Adopted by the Brazilian Judicial System; International Journal for Court Administration; Vol. 12 Issue 2, pp. 10, 2021

Sayer Andrew, Hess Melanie, Hall Matthew E. K., Affirming the District Judge: An Empirical Analysis of the Effect of District Judges Sitting by Designation on Circuit Court Panels; Journal of Empirical Legal Studies; Vol. 18 Issue 2, pp. 461-484, 2021

Scheppele Kim Lane, Kelemen R. Daniel, Morijn John, The EU Commission has to Cut Funding to Hungary: The Legal Case; 2021

Scheppele Kim Lane, Kochenov Dimitry Vladimirovich, Grabowska-Moroz Barbara, EU Values Are Law, after All: Enforcing EU Values through Systemic Infringement Actions by the European Commission and the Member States of the European Union; Yearbook of European Law; Vol. 39, pp. 3-121, 2021

Schoenaers Frédéric, Le Nouveau management public et la justice: les enjeux de la réforme du système judiciaire belge; 2021

Schotel Bas, Administrative Law as a Dual State. Authoritarian Elements of Administrative Law; Hague Journal on the Rule of Law; Vol. 13 Issue 1, pp. 195-222, 2021 
Seiler Moritz, Rezension: Odile Ammann, Domestic Courts and the Interpretation of International Law. Methods and Reasoning Based on the Swiss Example; «Justice - Justiz - Giustizia» $2021 / 2$

Semakula Joel, Res Judicata in Judicial Review; Judicial Review; Vol. 25 Issue 4, pp. 307-320, 2020

Shahshahani Sepehr, The Fact-Law Distinction: Strategic Factfinding and Lawmaking in a Judicial Hierarchy; Journal of Law, Economics, and Organization; Vol. 37 Issue 2, pp. 440-477, 2021

Simic Olivera, An introduction to transitional justice - Second edition; Abingdon, Oxon; Routledge, 2021

Skiple Jon Kåre, Bentsen Henrik Litleré, McKenzie Mark Jonathan, How Docket Control Shapes Judicial Behavior; Journal of Law and Courts; Vol. 9 Issue 1, pp. 111-136, 2021

Smahi Nadia, Due process under the Swiss rules of international arbitration; Bulletin ASA; $2020 / 930$

Sorabji John, Initial Reflections on the Potential Effects of the Covid-19 Pandemic on Courts and Judiciary of England and Wales; International Journal for Court Administration; Vol. 12 Issue 2, 2021

Sorel Sylvain, Tameghe Kuate, La justice, ses métiers, ses procédures; OHADA, Union africaine, CEEAC-CEMAC, CEDEAO-UEMOA, Nations Unies, Cameroun; 4e éd.; Paris; l'Harmattan, 2021

Sourdin Tania, Judges, technology and artificial intelligence: the artificial judge; Cheltenham, UK/Northampton, Massachusetts, USA; Edward Elgar Publishing Limited, 2021

Spamann Holger, Klöhn Lars, Jamin Christoph, Reidel Ivan, Judges in the Lab: No Precedent Effects, No Common/Civil Law Differences; Journal of Legal Analysis; Vol. 13 Issue 1, pp. 110126, 2021

Stoica Victor, Remedies before the International Court of Justice; Cambridge, UK/New York, NY; Cambridge University Press, 2021

Strother Logan, Glennon Colin, An Experimental Investigation of the Effect of Supreme Court Justices' Public Rhetoric on Perceptions of Judicial Legitimacy; Law \& Social Inquiry; Vol. 46 Issue 2, pp. 435-454, 2021

Subramanian Arun, A Titan among us - on Dissents, Waymaking, and strong Coffee; Columbia Law Review; Vol. 121:7

Terekhov Artur, Von der gebotenen Differenzierung zwischen Verfassungsgerichtsbarkeit gegenüber kantonalem Recht und Bundesrecht im Lichte der Gewaltenteilung; Ius.full: Forum für juristische Bildung 2020/162

Tettamanti Reto Andrea, Intertemporales Schiedsrecht: die für die Revision des 12. Kapitels IPRG relevanten Übergangsbestimmungen; Bulletin ASA; 2020/821

Ugwudike Pamela, Kohl Uta, Eisler Jacob, Data-Driven Algorithms in Criminal Justice: Prediction as self-fulfilling prophesy; University of Cambridge Press, 2021 
Wahedi Franziska, Verfassungsrechtliche Anforderungen an die Automatisierung der Justiz; Hamburg; Verlag Dr. Kovač, 2021

Wallace Anne, Laster Kathy, Courts in Victoria, Australia, During COVID: Will Digital Innovation Stick?; International Journal for Court Administration; Vol. 12 Issue 2, 2021

Wallenta Frank, Deutsche Staatsanwaltschaften zwischen Verfassungsrecht und europäischem Leitbild: eine Betrachtung des ministeriellen Einzelweisungsrechts im Lichte des unionsrechtlichen Anerkennungsprinzips; Baden-Baden; Nomos, 2021

Wanderer Ulrich (Hrsg.), Mediation - Lösungsansätze für Familien-, Erbschafts-, Nachbarschafts-, Datenschutz- und Wirtschaftskonflikte sowie Konflikte im öffentlichen Bereich; Wien; Linde Verlag, 2021

Wasserman Melissa F., Slack Jonathan D., Can There Be Too Much Specialization? Specialization in Specialized Courts; Northwestern University Law Review; v. 115 Issue 5, 2021

Watson Adam, Matevosyan Khachatur, Creating an Enabling Environment for Case Management System Implementations in the Justice Sector; «Justice - Justiz - Giustizia» 2021/2

Watt Graeme, Constitutional Innovation in the Supreme Court; Judicial Review; Vol. 25 Issue 4, pp. 341-352, 2020

Weber-Stecher Urs, Wirtschaftsmediation - ideale Ergänzung zur Schiedsgerichtsbarkeit; Anwaltsrevue; 2020/440

Weber Rolf H., Neue ADR-Formen für den ICT-Sektor; Sic ! : Zeitschrift für Immaterialgüter-, Informations- und Wettbewerbsrecht; 2020/730

Wiechmann Julia, Finanzfolgen höchstrichterlicher Entscheidungen; Baden-Baden; Nomos, 2021

Wiederin Ewald, From the Federalist Papers to Hans Kelsen's «Dearest Child»: The Genesis of the Austrian Constitutional Court; Zeitschrift für öffentliches Recht; Vol. 76 Issue 2, pp. 313, 2021

Wietlisbach Stephanie, Mediation als Chance bei Trennung oder Scheidung; Anwaltsrevue; $2020 / 459$

Wissler Ildiko, Mit Blockchain zur digitalisierten Justiz; «Justice - Justiz - Giustizia» 2021/2 